\title{
BRITISH MANUFACTURING INVESTMENT IN SUB-SAHARAN AFRICA: CORPORATE RESPONSES DURING STRUCTURAL ADJUSTMENT
}

\author{
by
}

\section{Paul Bennell*}

\begin{abstract}
A recently completed survey of British manufacturing investment in fourteen anglophone African countries indicates that there has been major disinvestment during the last five years. This process of corporate disengagement is occuring despite concerted attempts by African governments to improve the overall investment climate for both national and foreign investors. The article analyses the pattern of disinvestment by country and industrial sector and considers some of the key causal factors.
\end{abstract}

\section{INTRODUCTION}

This article presents and analyses the results of a recently completed survey that shows widespread disinvestment among UK manufacturing companies with subsidiaries and asscociate companies in anglophone Africa during the period 1989-1994. For the proponents of structural adjustment, such a process of disinvestment is potentially very serious. Rapid sustainable development of an efficient, internationally competitive private sector is the single most important medium-long term objective of structural adjustment programmes in sub-Saharan Africa (SSA). In order to achieve this objective, SSA governments, the World Bank and other multilateral and bilateral aid donors are placing increased emphasis on the need to attract substantial inflows of foreign direct investment (FDI), not only in order to increase historically very low rates of private investment but also to ensure access to modern technologies and world markets. Failure to do so, it is argued, will seriously affect the development of the private sector as a whole (and particularly its capacity to absorb new labour market entrants and retrenched public sector employees) and the gap in technological

\footnotetext{
Paul Bennell is a Fellow of the Institute of Development Studies at the University of Sussex. Reginald Green, Charles Harvey and two anonymous reviewers made very useful comments on an earlier draft of this paper. The usual disclaimers apply.
} 
capabilities between SSA and the rest of the world will widen still further with the concomitant danger that the continent as a whole will remain marginal to the on-going process of global economic integration.

Since the late 1980s, governments in SSA have started to make concerted attempts to improve the investment climate for transnational corporations and other foreign investors. Most have promulgated new investment codes that have swept to one side many of the restrictions and impediments that had so seriously limited FDI in the past and replaced them with a variety of investment incentives and guarantees. In addition, one stop investment centres have been established in order to respond to investment enquiries and to facilitate rapid approval of investment projects. While numerous impediments to increased FDI remain, for the first time the majority of SSA governments are actively wooing foreign investors. And, in contrast to pre-adjustment policy regimes, FDI is being targeted on manufacturing and other productive activities that are internationally competitive, preferably labour intensive and do not rely on excessive levels of protection, monopoly and clientelism.

In view of the importance that is attached to increasing FDI in SSA, the response of foreign investors to the new macroeconomic and investment policy regimes is of central importance in any assessment of the overall process of structural adjustment. Since most adjustment programmes in SSA were first introduced before 1987, it is possible to analyse what has happened to FDI over at least a 6-7 year period. ${ }^{1}$ With regard to investment promotion policies, significant reforms have only been enacted during the last 2-3 years. Thus, it is too early to make any meaningful assessment of their impact.

The available data on stocks and flows of FDI (most notably from the IMF and OECD) are notoriously unreliable and inconsistent and are too aggregated for detailed country and sectoral level analysis. Nonetheless, in its 1994 report 'Adjustment in Africa: Reforms, Results and the Road Ahead', the World Bank confidently states that "FDI increased slightly during adjustment, especially in the countries that improved economic policies. It rose in nine of the thirteen countries where policies improved and data were available 2 - and declined in six of the eleven countries where policies deteriorated" [World Bank, 1994:155].

The main objective of the above-mentioned survey is to analyse in detail a key segment of FDI during adjustment, namely British manufacturing investment in anglophone Africa. The fourteen countries that make up anglophone Africa have been categorised as follows:(i) Gambia, Ghana, Nigeria, Tanzania and Zimbabwe that have, according to the Adjustment in Africa Report made "large improvements in macroeconomic policies" during adjustment; (ii) Malawi, Kenya and Uganda that have made "slight improvements"; (iii) Sierra Leone and 
Zambia where macroeconomic policies "deteriorated"; and (iv) Botswana, Lesotho, and Swaziland who did not embark on Bank designed adjustment programmes and war torn Liberia. ${ }^{3}$ Collectively, these fourteen countries accounted for $54.6 \%$ of the total population and $58.3 \%$ of total manufacturing value added in sub-Saharan Africa in 1990.

Over $90 \%$ of UK manufacturing investment in SSA as a whole (excluding South Africa and Namibia) was located in anglophone countries in the early 1990s. Furthermore, British corporate investment typically comprises between $50-80 \%$ of all manufacturing FDI in each country. ${ }^{4}$ Consequently, recent trends in the level of British corporate involvement in SSA are not only important in their own right but may also be indicative of similar trends among manufacturing companies from other countries. For example, the number of German companies with Nigerian investments dropped from 66 to 44 between 1991 and 1993 [See Thompson, 1992].

The following assessment of British manufacturing FDI in anglophone SSA is based on two soures of data. The first is published and unpublished data from the annual Business Monitor surveys of Overseas Transactions and triennial Censuses of British Overseas Assets conducted by the UK Central Statistical Office (CSO). These data can be used to analyse overall trends in British manufacturing FDI in SSA during the period prior to the introduction of adjustment programmes in the early-mid 1980s and the five-ten years since the onset of these policy regimes.

The second set of data is two comprehensive surveys of all equity involvements by registered British companies in manufacturing activities in the 14 anglophone SSA countries undertaken by the author in 1989 and 1994 [see Bennell, 1990]. Both surveys sought to answer the following basic questions:

How many UK parent companies had on-going equity involvements in each country? What was the distribution of these involvements among parent companies?

What were the characteristics of these parent companies in terms of key size indicators (global turnover, employment, net assets and total number of countries in which they had subsidiaries and associates)?

What were the total number of equity involvements in each country and for each type of manufacturing activity? 
What was the overall pattern of equity involvements? In particular, what was the extent of minority shareholdings?

What have been the principal factors influencing the levels of equity involvements and what are the main constraints likely to impede higher levels of manufacturing investment in the future?

By comparing the number and patterns of equity involvements in the benchmark survey of 1989 with those in the five year follow-up survey in 1994, it is possible to obtain a detailed and accurate assessment of trends in British manufacturing FDI during a key phase of the adjustment process in Africa.

The full results of the survey have been presented elsewhere [See Bennell, 1994]. The purpose of this article is to analyse major trends in British manufacturing investment in SSA since the late 1980s and consider a number of possible factors and explanations. The discussion is organised as follows. First, the data used for the research are described in some detail. The second section examines the CSO data on the book value and net investments of British industrial investment before and during adjustment in SSA countries. The third section summarises the main findings of the 1989 and 1994 equity involvement surveys. A number of explanatory factors for the observed trends in British manufacturing in SSA, in particular during the period 1989-1994, are then analysed. The discussion concludes with an overall assessment of the response of British manufacturing FDI in SSA during adjustment and likely prospects in the medium-long term.

\section{DATA SOURCES}

The CSO's annual Business Monitor MA4 of Overseas Transactions gives detailed information on the net earnings, net investment and book values of British investments by geographical region and main recipient country disaggregated by sector. This is a very valuable source of up to date, good quality data that can be readily used for time series analysis. In addition, the CSO also made available unpublished data on net investment, net earnings, net assets, and dividends and profit remittances for the individual African countries included in the survey.

The main objective of the 1989 and 1994 surveys was to obtain detailed and accurate information on all equity involvements of British registered companies in substantive manufacturing activities in anglophone SSA countries. 5 These companies were initially 
identified using UK and African national company directories, lists of 'British connected' companies distributed by the British High Commission in each country and other relevant publications. For the initial survey in 1989, all parent companies were then written to and asked to confirm whether the company had an ownership stake in one or more manufacturing enterprises in any anglophone SSA country and, if so to provide information on the percentage of the equity held and the types of products manufactured. Obtaining this information was very time consuming but nevertheless essential because of the many errors and omissions contained in the company directories coupled with the difficulty of ascertaining whether the companies listed were actually engaged in manufacturing rather than just trade and/or service activities. In fact, further research undertaken for the 1994 resurvey revealed that nearly a quarter of the equity involvements originally enumerated in the 1989 survey were engaged in activities with no or very little manufacturing value added or were just 'shell' companies and thus dormant.

Only British companies registered under the UK companies Act were surveyed. British based companies with subsidiaries and associates 6 owned by foreign parent companies were originally excluded in the 1989 survey but were subsequently included in both survey years. Individual British nationals also have ownership stakes in manufacturing enterprises operating in survey countries. Little is known about these individuals, but from the names that are available many of them are of Asian descent. However, since they are not UK registered corporate entities, they have been excluded from both surveys.

UK companies with confirmed manufacturing equity involvements were requested to complete a short questionnaire on the activities of their subsidiaries and associates. A two page questionnaire was used in 1989 that asked companies to provide precise information on capital employed, turnover, net investment and profits for each activity. Twenty parent companies (out of a total of 90) with 39 equity involvements satisfactorily completed the questionnaire. In an attempt to improve the response rate, the 1994 questionnaire was just one page long and, for each involvement, parent companies were only asked to furnish the following information: (i) total employees and expatriates, the percentage change in the nominal value of production between 1989 and 1993, and the rate of return on capital employed in 1993; (ii) their future intentions (if any); (iii) the four factors in order of importance that would most encourage them to make further investments. In the event, the response rate was slightly higher with 19 parent companies (out of 65) with 58 equity involvements returning the questionnaire. ${ }^{7}$ While the perceived commercial sensitivity of the data requested was an important factor preventing completion, many companies stated that they were deluged with questionnaires of various kinds and senior managers did not have time to complete them. 


\section{BRITISH FDI BEFORE AND DURING ADJUSTMENT:AN OVERVIEW}

In global terms, manufacturing investment by British companies in Africa is relatively inconsequential. At the height of the economic crisis in Africa during the mid 1980s, net manufacturing UK investment IN SSA amounted to barely $0.5 \%$ of the world total. There has been some nominal increase in the overall level of UK manufacturing investment in Africa since then but, in real terms, average annual net manufacturing investment for all Africa (excluding South Africa) during 1988-1992 was only 10-15\% higher than during the period 1980-1987.

Table 1 shows total and manufacturing UK investment among anglophone SSA countries grouped according to the IBRD's three macroeconomic performance categories. For UK investment as a whole, a clear positive correlation exists between the percentage change in net investment and the degree of improvement in macroeconomic policies as adjudged by the World Bank. It should be noted however that changes in investment levels were highly uneven among countries in each performance category and the overall figures are dominated by one country. This highlights the serious limitations of making inter-group comparisons with only small numbers of countries.

Turning to manufacturing investment, an inverse relationship exists between changes in UK net investment and country macroeconomic performance, with the largest percentage increases in investment levels being recorded among countries with small improvements and deterioration in their overall macroeconomic policies and the smallest percentage increases in investment among countries with large improvements in their macroeconomic policies. While therefore the assertion made in the Adjustment in Africa Report that total FDI has improved slightly during adjustment is generally supported by the UK data, with regard to the manufacturing sector, the degree of country adjustment has had no systematic positive impact on net investment levels by UK companies. One possible explanation for this is that the effects of far reaching macroeconomic adjustments (in particular very sizeable devaluations) may have substantially dampened any increases in foreign investment, at least in the short run, whereas in countries where adjustment has been more limited or where there have been policy reversals, acute shortages of foreign exchange may have prevented foreign investors from remitting profits thus forcing them to re-invest locally. 8 


\section{UK EQUITY INVOLVEMENTS}

In mid 1989, 90 British companies had a total of 336 equity involvements in manufacturing enterprises in anglophone SSA countries. By mid 1994, there were only 65 companies with equity stakes in 233 manufacturing enterprises (see Table 2). In total, over half of the 1989 parent companies had disinvested - 28 (31.1\%) completely and another 20 (22.2\%) partially. This dramatic process of corporate disengagement has been concentrated in three countries - Kenya, Nigeria and Zimbabwe - where two-thirds of British equity involvements were located. At the very least therefore, adjustment in anglophone SSA has been unable to prevent widespread disinvestment and may well in fact have hastened the process (see below). Equally significant, it also appears that the level of disinvestment (as measured by equity involvements) is as high among the IBRD's high improvement countries as it is those countries that were categorised as poor performers.

The 1989 survey found that approximately one-third of UK companies with manufacturing equity involvements in the 14 survey countries in the late 1970s disinvested during the 1980s. It is clear, therefore, that the disinvestment that occurred in the period 1989-1994 represents a continuation, albeit accelerated, of an already well established process of corporate withdrawal. Some of the most important disinvesting companies included the following: Chloride and Lucas (car batteries), Leyland Trucks (vehicle assembly), Courtaulds (paper, packaging, paper), Boots and Wellcome (pharmaceutical), ICI (chemicals), Low and Bonar (textiles, plastics, engineering), Pilkington (glass), Raleigh (bicycles), Norcros (metal door and window frames), Silentnight (furniture), Whitecroft (plastics, office equipment), Bain and RTZ (tools, implements), Lonrho (paper, printing and packaging, food and drink), and Allied Lyons and Dalgety (food). Probably the largest and, in many ways, the most symbolic disinvestment was the sale in 1994 of most of Unilever's $40 \%$ stake in the United Africa Company in Nigeria.

In contrast, despite the concerted attempts by SSA governments and the Department of Trade and Industry to attract new British investment, only nine UK based companies (Bulmer, CDC, De La Rue, Glaxo, Guinness, Land Rover (British Aerospace) Lonrho, Paccar, Tollgate) invested in 18 new manufacturing investments in anglophone SSA between 1989 and 1994. Only three of these companies (Bulmer, Paccar and Tollgate) did not already have existing manufacturing equity involvements in SSA. The country breakdown of these new enterprises was as follows: Kenya, Zimbabwe (four each), Botswana, Malawi, Tanzania (two each), and Ghana, Nigeria, Swaziland and Zambia (one each). Food and drink and textiles and clothing each accounted for four of these new enterprises, wood and paper, metal goods, chemicals and rubber and printing and publishing two each, and electrical goods one. 
As has been shown elsewhere, these investments were made principally on the basis of company judgements about a country's economic and political stability coupled with fundamental market and cost considerations.

As in 1989, a small group of 20 parent companies continued to account for nearly $70 \%$ of all manufacturing equity involvements in anglophone SSA in $1994 .{ }^{9}$ The share of the two giants, Lonrho and Unilever increased slightly from $20.3 \%$ in 1989 to $22.4 \%$ in 1994 (although both of them disposed of some equity involvements during this period). As predicted in 1989, smaller, less involved British companies have been more inclined to disinvest. Whereas UK parent companies with one equity stake accounted for $11.2 \%$ of all involvements in 1989, their share had fallen to $7.8 \%$ in 1994.

Table 3 shows the distribution of equity involvements by industrial sector in 1989 and 1994 . While significant disinvestment took place across all sectors, the incidence of withdrawal was greatest in the intermediate and capital goods sector. By 1994, less than $30 \%$ of all manufacturing enterprises (56 in total) were engaged in the manufacture of metal goods and transport equipment and mechanical engineering. Disinvestment has therefore reinforced the already dominant pattern of UK equity involvements in the production of relatively low value added wage goods (most notably beer and spirits, cigarettes, soap and detergents, basic foodstuffs, plastic and rubber goods, textiles and clothing), bulky intermediate goods (such as cement), and a very limited range of metal and electrical goods. Most of these activities use relatively simple and increasingly out-dated technologies. With many parent companies continuing to run down their manufacturing investments in SSA, this has adversely affected the already limited process of technology transfer.

Disinvestment has not resulted in any major change in the overall pattern of equity involvement among UK parent companies in manufacturing enterprises in the survey countries. Parent companies were majority shareholders in $66.6 \%$ and $69.7 \%$ of manufacturing enterprises in 1989 and 1994 respectively. Equity participation was increased in just 12 enterprises and reduced in another 16 enterprises.

Expatriate, predominantly 'home country' managers and technicians were employed by UK parent companies in their subsidiaries and associates in SSA mainly because of the unavailability of local personnel with the requisite skills and experience to fill key management and technical positions and not, as is often suggested, in order to establish direct control over subsidiary operations. The number and incidence of expatriate personnel is a key indicator therefore of the development of national technological and management capabilities. Limited evidence from the questionnaire surveys suggests that reliance on 
expatriates actually increased between 1989 and 1993. This may be due to a number of factors including the need for more intensive management in rapidly deteriorating business environments coupled with the continued shortage of local managers with the requisite skills which, in some countries, has been exacerbated by international migration.

\section{DISINVESTMENT AND ADJUSTMENT}

The report of the 1989 survey identified unacceptably low levels of profitability over long periods of time due mainly to shortages of foreign exchange as being the principal reason for disinvestment by UK companies from SSA during the 1980s. "The really critical issue has been the chronic and persistent shortage of foreign exchange in SSA during the 1980s which has meant that, because subsidiaries have been unable to remit most of their profits (or have been subject to long delays), the effective rates of return in sterling terms to parent companies have been considerably less than the often quite respectable local currency rates of return" [Bennell, 1990:166]. Foreign exchange availability continued to be a key factor fuelling the much higher rate of disinvestment during 1989-1994.

Data could not be obtained on the (in-country) rates of return on capital employed in manufacturing enterprises from which UK companies had disinvested. ${ }^{10}$ However, these data are available for 72 enterprises where UK parent companies had active equity involvements in mid 1994. Overall rates of return on capital employed were higher among this group of enterprises than they were among the mainly different group surveyed in 1989. In particular, $54.4 \%$ had rates of return of $20 \%$ and higher compared with only $30.0 \%$ among the 1989 group. 11

The CSO Overseas Transactions and Assets data also indicate that the overall rate of return on UK manufacturing investments in Africa as a whole was slightly higher during 19881992 than the pre-adjustment period 1980-1987 (20.4\% and 17.4\% respectively). With the exception of electrical goods and "other manufacture" (which includes textiles and cement and bricks), rates of return on UK investments in Africa increased in all manufacturing subsectors in the period 1988-1992. However, there is no statistically significant relationship between the level of these sectoral rates of return and the incidence of disinvestment by sector .

Country level data are limited but what are available suggest that the largest increases in manufacturing (in-country) rates of return were in Kenya, Malawi and Zambia, countries that according to the IBRD's Adjustment in Africa Report had small improvements or deterioration in macroeconomic policies (see Table 4). In contrast, in two out of the three 
countries categorised by this Report as having made large improvements in macroeconomic policies and for which data are available, rates of return on UK manufacturing investments fell appreciably (Nigeria) or remained largely unchanged (Zimbabwe) between the preadjustment and adjustment time periods.

Decomposing each rate of return estimate into its two constituent parts (ie. net earnings and capital employed) is also illuminating. It can be observed in Table 4 that the average annual net earnings from UK manufacturing investments fell substantially between 1980-87 and 1989-92 in Nigeria and Tanzania which had large improvements in macroeconomic policies, but increased appreciably in the three countries that either had small improvements or deterioration in their adjustment regimes. In the case of Kenya and Zambia, however, higher net earnings were offset by significant declines in the book value of UK manufacturing net assets of $44.2 \%$ and $34.1 \%$ respectively which, to a large extent, were due to currency devaluations.

According to the CSO data, rates of returns (based on net earnings) for UK manufacturing investments in Africa compared quite favourably with other regions of the world throughout the 1980 s and early $1990 \mathrm{~s}^{12}$ (see Table 5). A common observation made by senior managers of UK parent companies is that, given the considerable risks involved in investing in Africa coupled with often high overhead costs, rates of return have to be higher than elsewhere if their companies are to continue to operate in difficult business environments.

Without knowing what rates of return were among disinvesting companies, it is impossible to say to what extent profitability per se has been the key factor responsible for disinvestment in Africa. While the CSO survey data indicate that aggregate profitability of manufacturing investments for the continent as a whole was relatively high in the mid-late 1980s, it may well be that for significant numbers of individual manufacturing enterprises, profitability reached unacceptably low levels.

While it is clear that factors other than short-term profitability have influenced investment levels (in particular, investor perceptions of the credibility of economic reforms over the long run), the translation of subsidiary profits into sterling remittances for parent companies and their shareholders in the UK remains the fundamental issue for all foreign investors. The value of sterling remittances is determined by two factors-the percentage of profits that are actually remitted and the rate of exchange at which this transaction is undertaken. Surprisingly, CSO data indicate that the share of net earnings from UK manufacturing investments in Africa remitted each year to the UK was higher than the global average between 1985 and 1990 (34.3\% compared with 26.6\%). Why then has the rate of profit 
remittance been such a critical concern for UK investors in Africa? The most plausible explanation is that while UK companies have been keen to reinvest very sizeable proportions of their profits in North America, Europe and Asia, investment opportunities in manufacturing have generally been very limited in Africa and thus, given the option, most parent companies would like to remit the bulk of subsidiary profits from the region.

By making foreign exchange more available, adjustment should enable foreign investors to remit higher proportions of their locally generated profits than hitherto. However, Table 6 shows that, with the exception of Zimbabwe, the share of profits remitted to the UK actually fell or stagnated in adjusting countries. This would suggest that either that liberalisation of foreign exchange markets has not in fact enabled UK subsidiaries to gain greater access to foreign exchange or that those companies that are deciding to stay are voluntarily deciding to re-invest a greater share of their profits. Whatever the reason, the fact remains that, with at best only one-third of profits being remitted in most survey countries, sterling rates of return (net of local taxes) for manufacturing investments were typically well under $10 \%$ (see below).

The other determinant of the sterling value of profit remittances from investment overseas is the prevailing rate of exchange. There were major currency devaluations in virtually all anglophone SSA countries during the period 1989-1994, most of which were part and parcel of adjustment programmes. While devaluation gives the manufacturing sector increased protection from competitive imports, it increases the cost of imported raw materials which many industries remain heavily reliant upon. Just what impact changes in the costs of now more available imported inputs have on profits will depend on the extent to which they can be passed on in higher prices coupled with changes in the overall level of demand and possible productivity improvements resulting from higher rates of capacity utilisation. But the most serious immediate impact on foreign investors of any large devaluation is that it reduces the sterling value of profit remittances by the same percentage amount. With continuous devaluations, this problem is further compounded the longer the delays that are encountered in remitting profits.

Although information on subsidiary profits was not requested as part of the parent company questionnaire, data were collected on the percentage change in the nominal value of production expressed in local currency units for each equity involvement. When deflated by the percentage devaluation of each national currency against sterling during the same period, this yields the percentage change in nominal production expressed in pounds sterling. In total, production data were obtained for 61 wholly and partially British owned manufacturing subsidiaries in anglophone SSA countries. It can be observed in Table 7 that 
for nearly 55\% of these subsidiaries, the sterling value of production declined between 1989 and 1993. For 26 subsidiaries (42.6\% of the total), this decline was more than $25 \%$ of the 1989 sterling value of production.

Among the 25 manufacturing enterprises for whom employment data are available in both 1989 and 1994, 12 (44.0\%) reported declines in the number of employees, and another four no change. By sub-sector, metal goods, textiles, cement and publishing had overall increases in employment while electrical goods, food and drink and chemicals and rubber had overall falls. Employment increased in Nigeria and Zimbabwe by $13-14 \%$ but fell in Kenya by $11.3 \%$. Although these data are limited, they provide further evidence of contracting activity among a sizeable proportion of UK subsidiary and associate companies in SSA during adjustment.

From unpublished CSO survey data, it is possible to ascertain the overall impact of adjustment on the sterling profitability of UK manufacturing investments in five individual survey countries as well as in Africa as a whole. Comparing the pre-adjustment period 198087 with 1988-92, the largest percentage increases in the value of sterling profits remitted to the UK were recorded in the two countries (Kenya and Malawi) categorised by the Adjustment in Africa Report as having made only small improvements in macroeconomic policies. Sterling profits plummeted in Nigeria and Zambia. They recorded a healthy increase in Zimbabwe but adjustment did not effectively start until 1991.

Higher sterling profits were achieved in Kenya, Malawi, and Zimbabwe despite very sizeable devaluations, no significant increases in (low) rates of profit remittance, and actual falls in the sterling value of production for at least one half of all UK subsidiaries. However, as was discussed earlier, these negative factors were counteracted in some countries by generally higher rates of return (in local currency units) which, in turn, could only have been achieved by companies increasing their margins (ie. or the rate of profit on turnover). This could have been part of a deliberate strategy by some UK subsidiaries to maximise short run profits immediately prior to widely anticipated increases in import competition in the later stages of adjustment.

Although absolute sterling profits increased in some countries during adjustment, the overall impact on sterling rates of return was minimal. It can be observed in Table 6 that these rates of return ranged from 3.5-6.4\% in all five countries for which data are available. The overall rate for Africa was just $6.0 \%$. Thus, although there was some improvement in sterling rates of return for some countries, adjustment has not yet resulted in sufficiently large increases that would make manufacturing investments in SSA attractive in global terms. 
Generally speaking, senior mangers of UK companies tend to be highly critical of adjustment in SSA. Common complaints are that adjustment programmes are too simplistic and "naive", fail to take into account local conditions, and have been too rapidly implemented in many countries. There is widespread concern that the short term costs of adjustment on manufacturing in Africa are so great, that there may be "nothing left" in the medium to long term. Reactions of this kind are consistent with the companies concerned having been highly protected and finding it difficult to survive after trade liberalisation. Clearly, therefore, where foreign owned enterprises are irredeemably inefficient, disinvestment is likely to be beneficial.

Quite apart from concerns about profitability, the decision to disinvest by a number of important British companies in the manufacturing sector in SSA has been primarily motivated by an overriding strategic objective to "concentrate on core activities" in their principal markets worldwide. They have therefore sold their manufacturing interests that lie outside of these core activities, not only in Africa but elsewhere in the world. For a company like Unilever that has invested in a wide range of manufacturing activities during the last 4050 years (in particular in Nigeria), this "refocusing" of global activities clearly has major implications for their future involvement in Africa. 13

More generally, the acute and persistent difficulties that confronted UK parent companies throughout the 1980s and into the 1990s in managing their manufacturing subsidiaries in SSA prompted many of them to sell what were usually very minor parts of their global operations. In Nigeria, for example, one manager wrote, "We divested earlier this year (1994). I am afraid the economic, political and social background made the running of the subsidiary business untenable". Similarly, the 1992 Annual Report of Low and Bonar plc states "The sale of remaining African businesses marked the end of an era going back almost seventy years. The business climate there has been exceedingly difficult for some time and with the opportunity of remitting dividends proving difficult, a sale was in the best interests of our shareholders" [Low and Bonar, 1992:8]. It is because UK managers have grown so weary of dealing with all the problems of manufacturing in Africa that probably explains why disinvestment has been so pervasive and why it is difficult therefore to discern any distinct patterns of disinvestment with respect to sector, profitability and rates of return.

Finally, most UK parent companies are not prepared to disinvest unless there is a willing buyer who is prepared to pay a realistic price for their equity stake. Where therefore a country has a relatively well developed indigenous industrial class (as is the case in 
Zimbabwe, Kenya and, to a lesser extent, Nigeria) then one would expect, ceteris paribus, relatively higher levels of disinvestment.

Disinvesting companies were often reluctant to divulge information about the new owners of their erstwhile subsidiary and associate companies. Finding out to whom equity stakes have been sold will require therefore more detailed research. But on the basis of the information obtained so far, the following ownership patterns seem to be emerging: (i) Perhaps not surprisingly, very few companies were bought by other transnational corporations, either from the UK or other major industrial countries; (ii) The relatively well developed, albeit white, business class in Zimbabwe has been very willing to acquire the manufacturing interests of disinvesting British companies, often in the form of management buy-outs. There is also some evidence of growing South African involvement; (iii) In Kenya, local Asian industrialists have been the main group of buyers; and (iv) In Nigeria, disinvesting companies were particularly reluctant to divulge the identity of the new owners. This was probably because a sizeable proportion of purchases were made off-shore by Nigerians, quite possibly using the proceeds of illegal transactions.

\section{DISINVESTMENT AND DEINDUSTRIALISATION}

It is difficult (although not impossible) to reconcile the widespread withdrawal of UK manufacturing companies from SSA between 1989 and 1994 with the optimistic assessment presented in the IBRD's Adjustment in Africa Report of the impact of adjustment policies on manufacturing enterprise coupled with its strong refutation of persistent criticisms that adjustment is resulting in the rapid deindustrialisation of Africa. It is important to note, however, that the statistics used in this Report to show that "industry is expanding" (in particular, in the countries with the largest improvements in macroeconomic policies) do not go beyond 1991. All the evidence (albeit fragmentary) for the period 1992-94 indicates that the value of manufacturing production in almost all survey countries fell substantially. In particular, in some countries (such as Ghana), it was not until the early 1990s that trade liberalisation measures really started "to bite" [See Lall et al, 1993].

In Zimbabwe, manufacturing industry contracted by $40 \%$ in 1992 and another $16.8 \%$ during the first eight months of 1993. While the effects of a serious drought were partially responsible for these falls in production, the Confederation of Zimbabwe Industry clearly identified very high interest rates, shortage of money supplies and increased foreign competition as the major causes. Writing in September 1993, the President of the CZI stated that "What we have in Zimbabwe is a road to economic ruin and deindustrialisation" [CZI, 
1993:21]. In Zambia, the Chamber of Commerce and Industry reported that $17 \%$ of its members were forced to close during 1993 and predicted that this figure would rise to $25 \%$ in 1994. Local markets were flooded by cheap imports from Zimbabwe and South Africa and production costs remained high boosted by large increases in electricity tariffs and wages. [See DTI, 1994]. In Nigeria, the manufacturing sector was reported to be on "the verge of collapse" in mid 1993 [Thompson, 1992:35].

Whether or not the acute problems faced by manufacturing sectors in anglophone SSA during 1991-1994 are, to use the anodyne terminology of the Adjustment in Africa Report, just part of "a difficult transition phase" [op cit:149] or the manifestations of a far more serious process of deindustrialisation cannot yet be satisfactorily answered. However, it is clear that economic conditions during the greater part of the period 1991-1994 did deteriorate in most of these countries. For UK parent companies this was undoubtedly the major factor that for many of them tipped the balance in favour of disinvestment.

Disinvestment per se need not be harmful for the industrial prospects of SSA countries. Dependency theorists will no doubt welcome the curtailment of what they see as the exploitation of small, poor economies by an important segment of international capital. Clearly, a key question is what will happen to previously British owned manufacturing enterprises? What will happen to wage levels and employment? Will their new owners maintain current industrial capacity or asset strip? How efficiently (and ethically) ${ }^{14}$ will they be managed? What links, if any, will be established with the old parent company or other foreign companies that will ensure access to new technologies, management and technical skills, and overseas markets? "Externalised" forms of involvement by TNCs such as these are increasingly common in developing countries. They generally entail considerably less risk and are potentially lucrative with assured payments in foreign exchange for services rendered. [See UNCTC, 1989 and UNCTAD, 1994].

The experience of Japan and the NICs highlights the importance of being able to learn from foreigners, especially during the early stages of an industrialisation process. The precise modalities of this learning process have varied considerably from one country to another. Some countries like Singapore have relied mainly on direct foreign investment while others (most notably South Korea) have used more arms length technical agreements with technology suppliers and overseas training institutions. Although there are some exceptions, foreign investment in Africa has not resulted in the same kind of dynamic learning process as in other countries. It is clearly important to understand the reasons for this. It is conceivable that disinvestment could mark the start of new relationships between parent 
companies and their erstwhile subsidiary and associate companies in SSA that result in more positive learning outcomes.

\section{FUTURE PROSPECTS:THE DE-INDUSTRIAL DECADE FOR AFRICA?}

Two principal conclusions emerge from this research. First, there has been widespread disinvestment by UK parent companies with manufacturing equity involvements in anglophone SSA between 1989 and 1994. Thus, the really key issue for those concerned to promote FDI is as much how to keep what foreign investment remains as it is to attract new inflows. As was noted in the 1989 survey, "most industrial FDI in SSA will depend on the response of existing tncs to growth in local markets for their products. For nearly all the survey countries, their overall economic growth will continue to be based on heavily on agricultural and mineral exports, the longer-term prospects for which remain poor" [op cit:172]. Nothing has changed in the interim to alter this assessment.

Asked about their future intentions, most UK company questionnaire respondents indicated that they expect to maintain and, where real opportunities arise, increase their manufacturing activities in SSA. 15 But, as Table 8 shows, the overall level of concern about foreign exchange issues (in particular, overall forex availability, dividend remittance, and exchange rate stability) among company respondents increased quite significantly between the 1989 and 1994 surveys. 16 Unless, therefore, persistent and deep-seated foreign exchange problems can be satisfactorily resolved then the prospects for significant increases in manufacturing FDI even among existing investors remain bleak. This highlights yet again the key importance of economic and political "fundamentals" in determining the overall level of FDI to any particular country. As one company respondent succinctly put it, "The issues which cause us to make investments are mostly economic rather than government regulations/policies.. We do not see any economic/market justification for making any further external investment". More generally, as long as UK and other investors remain uncertain about the attitudes of SSA governments towards FDI, then there is little likelihood of any major changes in investor behaviour. In particular, privatisation remains stalled in many SSA countries precisely because of political sensitivities concerning the selling off of state assets to foreigners or white and Asian nationals. This sends clear signals that underlying anti-FDI attitudes that prevailed in the pre-adjustment era have not really changed.

There is a core group of UK companies mostly with multi-country interests in SSA who will continue to take a long term view and, in the words of a senior UK manager, "hang on in the 
hope that things will get better". But other companies will continue to leave. Just when they actually disinvest will depend to a large extent on the availability of suitable buyers. Looking at current trends, there may be no more than 30-40 UK companies with equity involvements in manufacturing enterprises by the end of the Second Industrial Decade in Africa. ${ }^{17}$

With so much disinvestment having taken place and with more in prospect, it is perhaps not surprising that SSA governments are finding it so difficult to privatise state-owned manufacturing enterprises many of which are little more than 'white elephants'. Certainly the expectation has been that major transnational corporations will purchase these enterprises but this seems increasingly unlikely. 18

It is not possible to determine at this stage whether corporate disinvestment is directly linked to a process of adjustment-induced de-industrialisation in Africa. What is clear however is that UK corporate disengagement is the result of stalled industrialisation in the continent. Sterling rates of return on UK manufacturing investments are simply too low for most companies and the business environment so difficult that disinvestment has been the inevitable consequence. In assessing the costs and benefits for African countries of this process of disinvestment, much will depend on the managerial and technical skills and future intentions of the new owners of erstwhile British companies. Without large scale and sustained technical and managerial assistance from foreign companies, there is a real danger that indigenous technological capacities particularly in more complex product sectors will continue to remain seriously deficient.

The second main conclusion of this research is that adjustment in anglophone SSA countries, while not the direct cause of disinvestment, has for most British manufacturing companies exacerbated already very difficult business conditions. The impact of massive devaluations on the sterling values of production and profits for parent companies and their shareholders has been particularly serious. While the debate continues about the costs and benefits of adjustment for industrial development in Africa, adjustment has undermined the resolve of a very sizeable proportion of UK companies to continue to operate in SSA. Generally speaking, given that "Africa did not recover after 1985" [Mosley and Weeks, 1993:1589], it is not surprising that by the early 1990s so many UK companies decided to sell up. The proponents of adjustment may argue that this is part of an unavoidable process of "rationalization" of inefficient manufacturing sectors. But, for those concerned about the long term industrial development of African countries, adjustment has often been introduced too quickly and provided too few incentives for potentially viable manufacturing enterprises to modernise and become competitive. 


\section{NOTES}

1. According to Mosley and Weeks, adjustment programmes were in place in Kenya, Malawi, Nigeria, Sierra Leone and Zambia before 1985 and introduced during 1985-87 in Gambia, Tanzania, and Uganda. However, Zimbabwe did not embark on full fledged adjustment until late 1990. [See Mosley and Weeks, 1993].

2. Just what these data are is not stated but presumably they are drawn from the IMF.

3. British FDI in South Africa and Namibia have not been included in this study. Cameroon, although partly English speaking, is mainly Francophone in character, as are the island states of Seychelles and Mauritius. Ethiopia and Sudan were also excluded.

4. Precise country level data on the composition of FDI by country are not available. These estimates were obtained from various sources including [Widstrand 1975], [Cable and Persuad 1987], [Clarke 1980], [Stoneman 1979], and [Bennell 1984].

5. Enterprises covered by the surveys include all manufacturing listed in sections 2-4 of the Standard Industrial Classification (SIC). Tea factories were excluded.

6. Definitions of subsidiaries and associate companies vary. However, for the purposes of this research, a subsidiary is defined as having more than $50 \%$ equity involvement by the UK parent company and an associate has less than $50 \%$.

7. Companies that completed the survey questionnaires in 1989 and 1994 comprised fairly representative samples (in terms of size and sector) of both UK parent companies and SSA enterprises from their respective populations.

8. This highlights the importance of distinguishing clearly between FDI from internally generated profits and new injections of externally funded FDI. The standard sources of FDI statistics, the IMF and OECD, do not make this distinction.

9. These companies are as follows: Allied Lyons, BAT, Blue Circle, BOC, Cadbury Schweppes, CarnaudMetalBox, Coates, the Commonwealth Development Corporation, GEC, Grand Metropolitan, Guinness, Longman, Lonrho, Paterson Zochonis, Reckitt and Colman, Sara Lee Corporation, Smithkline Beecham, Tate \& Lyle, T \& N, and Unilever.

10. Virtually all disinvesting companies stated that there was little or not point in them participating in the survey.

11. However, among the 14 enterprises (wholly or partially owned by six UK parent companies) where data are available for both survey years, $6(42.9 \%)$ had lower RORs in 1994, $5(35.7 \%)$ had RORs that were in the same ROR range, and only $3(21.4 \%)$ had RORs that were in higher ROR ranges.

12. For all UK overseas investments, the ROR in SSA was 30.3\% in 1990. This was higher than any other region in the world: $28.1 \%$ Asia, 6.2\% North America, 10.1\% Latin America and the Caribbean, and $11.2 \%$ Europe. 
13. With the departure of Tiny Rowland in October 1994, Lonrho may well sell a considerable proportion of its manufacturing subsidiary and associate companies in Africa in order to concentrate on its "central businesses" of mining, agriculture, and general trading.

14. A senior manager of a major UK multinational that had disinvested from Nigeria stated that "Asian businessmen are prepared to do things that we as a major multinational cannot do". Similar statements were commonly expressed by UK managers, suggesting that disinvestment could result in a decline in business ethics that could adversely affect attempts to improve democracy and establish 'good government'.

15. Among the 14 parent companies who provided information, nine gave strong positive indications that they plan to maintain and, when appropriate, increase their activities in SSA (in the form of increased investment and/or shareholding). Only three stated that they had no specific plans. One respondent indicated that they would sell two of their investments if suitable buyers become available. However, it is important to make a clear distinction between the reinvestment of internally generated profits and new injections of investment funding from overseas sources. It is likely that most investment will be of the former type.

16. Respondents were asked the following question: What (four) actions by host countries would most encourage your company to increase its level of investment in these (SSA) subsidiaries/associates? In 1989, 39.5\% of all responses concerned foreign exchange issues compared with $56.0 \%$ in 1989.

17. In addition, quasi-public organisations such as the Commonwealth Development Corporation and the International Finance Corporation which are politically mandated to continue to invest in manufacturing activities in Africa will become increasingly important.

18. Unless parastatal enterprises are strongly export-oriented, the risk of sizeable devaluations is likely to be a major deterrent for potential buyers especially if substantial new investment is required in order to restore/achieve acceptable levels of efficiency and output. In addition, the prospect of major import liberalisation programmes constitutes a major threat. 


\section{REFERENCES}

Bennell, P.S., 1984, 'Industrial Class Formation in Ghana:Some Empirical Observations', Development and Change, Vol. 15, No. 2, pp.591-614.

Bennell, P.S., 1990, 'British Industrial Investment in Sub-Saharan Africa: Corporate Responses to Economic Crisis in the 1980s', Development Policy Review, Vol. 8, No. 2 pp.155-178.

Cable, V. and Persaud, B. (eds.), 1987, Developing with Foreign Investment, London: Croom Helm.

Clarke, D., 1980, Foreign Companies and International Investment in Zimbabwe, London: Catholic Institute for International Relations.

Confederation of Zimbabwe Industry, 1993, Monthly Newsletter, September and November.

Department of Trade and Industry, various years, Business Monitor M4 Overseas Transactions, London: HMSO.

Department of Trade and Industry, 1978, 1981, 1984 and 1987, Triennial Census of British Assets Overseas, London: HMSO

Department of Trade and Industry, 1994, Zambia: Six Monthly Economic Report for the Period Ending March 1994, London,DTI.

Lall, S., Navaretti, G.B., Teitel, S. and Wignaraja, G., 1993, Technology and Enterprise Development: Ghana Under Structural Adjustment, Regional Program on Enterprise Development Case Study Series, Washington: World Bank.

Mosley, P. and Weeks, J., 1993, 'Has Recovery Begun? "Africa's Adjustment in the 1980s" Revisited', World Development, Vol. 21, No. 10 pp.1583-1606.

Stoneman, C., 1979, 'Foreign Capital in Zimbabwe', in UNCTAD, Towards a New Order in Zimbabwe, Geneva: UNCTAD.

Thompson, T., 1992, 'The Carrots are Many but the Nibbles are Few', $\underline{\text { African Business, }}$ April. 
UNCTAD, 1994, World Investment Report 1994, New York and Geneva: United Nations.

UNCTC, 1989, Transnational Corporations in World Development: Trends and Prospects, New York: UNCTC.

UNIDO, 1993, African Industry in Figures 1993, Vienna: UNIDO.

Who Owns Whom, various years, London: Dunn and Bradsheet

Widstrand, C. (ed.), 1975, Multinational Firms in Africa, Uppsala: Scandinavian Institute for African Studies.

World Bank and United Nations Programme, 1989, Africa's Adjustment and Growth in the 1990s, Washington and New York: World Bank and UNDP.

World Bank, 1993, World Development Report 1993, Oxford: Oxford University Press.

World Bank, 1994, Adjustment in Africa: Reforms Results and the Road Ahead, Oxford: Oxford University Press. 
Table 1: Average annual net investment by British companies in anglophone SSA by country and macroeconomic performance, 1980-1987 and 1988-1992 (£.million).

\begin{tabular}{|c|c|c|c|c|c|c|}
\hline \multirow[b]{2}{*}{ Country } & \multicolumn{3}{|c|}{ Manufacturing } & \multicolumn{3}{|c|}{ All } \\
\hline & 1980-87 & 1988-92 & $+/-$ & 1980-87 & 1988-92 & $+/-$ \\
\hline \multicolumn{7}{|c|}{ Large improvements } \\
\hline Gambia & 0.0 & 0.0 & & -0.3 & -1.0 & - \\
\hline Ghana & -0.5 & 0.8 & + & 3.6 & 30.6 & + \\
\hline Nigeria & 11.1 & 16.4 & + & 18.0 & 85.5 & + \\
\hline Tanzania & 1.1 & 1.0 & - & 2.6 & 1.0 & - \\
\hline Overall & 12.7 & 18.2 & & 23.9 & 107.5 & + \\
\hline \multicolumn{7}{|c|}{$\underline{\text { Small improvements }}$} \\
\hline Kenya & 8.5 & 13.8 & + & 18.8 & 30.2 & + \\
\hline Malawi & 1.9 & 3.8 & + & 7.9 & 6.8 & - \\
\hline Uganda & 0.2 & - & & -0.6 & 1.2 & + \\
\hline Overall & 10.4 & 17.6 & & 26.1 & 38.2 & + \\
\hline \multicolumn{7}{|l|}{$\underline{\text { Deterioration }}$} \\
\hline Sierra Leone & 0.8 & 0.1 & - & 0.5 & 3.0 & - \\
\hline Zambia & 6.5 & 13.0 & + & 17.6 & 19.6 & + \\
\hline Overall & 7.3 & 13.0 & & 18.1 & 22.6 & + \\
\hline \multicolumn{7}{|l|}{$\underline{\text { Others }}$} \\
\hline Botswana & 0.2 & -0.2 & - & -0.1 & 2.8 & + \\
\hline Swaziland & - & - & & 3.0 & 1.0 & - \\
\hline Overall & - & - & & 2.9 & 3.8 & + \\
\hline
\end{tabular}

Source: CSO, Overseas Transactions, MA4 Business Monitor

Notes: Zimbabwe has been excluded from the large improvement group because the adjustment programme did not effectively begin until mid 1991. 
Table 2: Parent companies and equity involvements by country and macroeconomic performance category, 1989 and 1994.

\begin{tabular}{|c|c|c|c|c|c|c|}
\hline \multirow[b]{2}{*}{ Country } & \multicolumn{3}{|c|}{ UK Parent Companies } & \multicolumn{3}{|c|}{ Equity Involvements } \\
\hline & 1989 & 1994 & $\%$ & 1989 & 1994 & $\%$ \\
\hline \multicolumn{7}{|c|}{ Large improvements } \\
\hline Gambia & 1 & 0 & -100.0 & 1 & 0 & -100.0 \\
\hline Ghana & 10 & 7 & -30.0 & 15 & 13 & -13.3 \\
\hline Nigeria & 47 & 33 & -29.8 & 71 & 49 & -31.0 \\
\hline Tanzania & 6 & 3 & -50.0 & 6 & 3 & -50.0 \\
\hline Zimbabwe & 58 & 43 & -25.9 & 95 & 66 & -29.0 \\
\hline Sub-total & 75 & 55 & -26.7 & 188 & 131 & -30.3 \\
\hline \multicolumn{7}{|c|}{ Small improvements } \\
\hline Kenya & 43 & 28 & -34.9 & 60 & 36 & -40.0 \\
\hline Malawi & 13 & 9 & -30.8 & 19 & 14 & -26.3 \\
\hline Uganda & 8 & 5 & -37.5 & 9 & 5 & -44.4 \\
\hline Sub-total & 45 & 33 & -26.7 & 88 & 55 & -37.5 \\
\hline \multicolumn{7}{|l|}{$\underline{\text { Deterioration }}$} \\
\hline Sierra Leone & 2 & 2 & 0.0 & 3 & 3 & 0.0 \\
\hline Zambia & 20 & 16 & -20.0 & 34 & 23 & -32.3 \\
\hline Sub-total & 21 & 17 & -23.5 & 37 & 26 & -29.7 \\
\hline \multicolumn{7}{|l|}{$\underline{\text { Others }}$} \\
\hline Botswana & 7 & 6 & -14.3 & 7 & 7 & 0.0 \\
\hline Lesotho & 2 & 1 & -50.0 & 2 & 1 & -50.0 \\
\hline Liberia & 2 & 2 & 0.0 & 2 & 2 & 0.0 \\
\hline Swaziland & 7 & 6 & -14.3 & 12 & 11 & -8.3 \\
\hline Sub-total & 14 & 12 & -14.3 & 23 & 21 & -8.7 \\
\hline Africa & 90 & 65 & -27.8 & 336 & 233 & -30.6 \\
\hline
\end{tabular}


Table 3: UK equity involvements by manufacturing sector, 1989 and 1994.

\begin{tabular}{|l|ccc||ccc|}
\hline & \multicolumn{5}{|c||}{ Number involvements } & \multicolumn{3}{c|}{ Percentage breakdown } \\
& $\mathbf{1 9 8 9}$ & $\mathbf{1 9 9 4}$ & $\mathbf{\%}$ & $\mathbf{1 9 8 9}$ & $\mathbf{1 9 9 4}$ & Difference \\
\hline & & & & & & \\
Food, drink & 71 & 55 & -22.5 & 21.1 & 23.6 & 2.5 \\
Textiles, clothing & 25 & -16.0 & 8.9 & 8.9 & 10.7 & 1.8 \\
Wood, paper & 14 & 6 & -57.1 & 4.2 & 2.6 & -1.6 \\
Chemicals, rubber & 95 & 65 & -46.1 & 28.3 & 27.9 & -0.4 \\
Cement, bricks & 17 & 13 & -23.5 & 5.1 & 5.6 & 0.5 \\
Metal goods & 38 & 27 & -40.7 & 11.6 & 11.3 & -0.3 \\
Mech. engineering & 16 & 11 & -31.3 & 4.8 & 4.7 & -0.1 \\
Electrical goods & 23 & 8 & -65.2 & 6.8 & 3.4 & -3.4 \\
Transport & 14 & 7 & -50.0 & 4.2 & 3.0 & -1.2 \\
equipment & & & & & & -0.5 \\
Printing & 6 & 3 & -50.0 & 1.8 & 1.3 & 2.0 \\
Publishing & 12 & 13 & 8.3 & 3.6 & 5.6 & 0.0 \\
\hline Totals & 336 & 233 & -30.7 & 100.0 & 100.0 & \\
\hline
\end{tabular}


Table 4: Net earnings, value of assets and in-country rates of return for British manufacturing subsidiaries and associate companies in Africa, 1980-87 and 1988-92

\begin{tabular}{|c|c|c|c|c|c|c|c|}
\hline \multirow[b]{2}{*}{ Country } & \multicolumn{3}{|c|}{ Net earnings (£m) } & \multicolumn{2}{|c|}{$\begin{array}{l}\text { Book value net } \\
\text { assets (£m) }\end{array}$} & \multicolumn{2}{|c|}{ Rate of return } \\
\hline & 1980-87 & 1988-92 & $\%$ & 1987 & 1992 & 1980-87 & 1988-92 \\
\hline \multicolumn{8}{|c|}{$\underline{\text { Large improvement }}$} \\
\hline Nigeria & 28.6 & 21.8 & -23.8 & 103 & 89 & 27.8 & 24.5 \\
\hline Tanzania & 0.6 & 0.2 & -66.7 & 8 & 2 & 7.5 & 10.0 \\
\hline Zimbabwe & 29.5 & 32.0 & 8.5 & 141 & 159 & 20.9 & 20.1 \\
\hline Sub-total1 & 29.2 & 22.0 & -24.7 & 111 & 91 & 26.5 & 25.3 \\
\hline \multicolumn{8}{|c|}{$\underline{\text { Small improvement }}$} \\
\hline Kenya & 11.6 & 18.8 & 62.0 & 156 & 87 & 7.4 & 21.6 \\
\hline Malawi & 1.9 & 5.2 & 173.7 & 24 & 30 & 7.9 & 17.3 \\
\hline Sub-total & 13.5 & 24.0 & 77.8 & 180 & 117 & 7.5 & 20.5 \\
\hline \multicolumn{8}{|c|}{ Deterioration } \\
\hline Zambia & 10.0 & 13.0 & 30.0 & 44 & 29 & 22.7 & 44.8 \\
\hline Africa & 117.0 & 132.6 & 13.3 & 669 & 649 & 17.5 & 20.4 \\
\hline
\end{tabular}

Notes: 1 Zimbabwe excluded for reason given in Table 2 
Table 5: Net earnings as a percentage of book values of UK overseas manufacturing investments by region, 1978-91

\begin{tabular}{|rrrrrrrr|}
\hline Year & Europe & $\begin{array}{c}\text { North } \\
\text { America }\end{array}$ & $\begin{array}{c}\text { Other } \\
\text { developed }\end{array}$ & Africa & Asia & $\begin{array}{c}\text { Latin } \\
\text { America }\end{array}$ & Overall \\
\hline 1978 & 9.0 & 9.3 & 12.6 & 11.9 & 12.2 & 11.4 & 9.5 \\
1981 & 5.4 & 12.8 & 17.6 & 11.0 & 15.3 & 22.9 & 12.7 \\
1984 & 9.0 & 7.9 & 11.0 & 12.0 & 22.2 & - & 10.1 \\
1987 & 15.0 & 15.9 & 15.5 & 17.9 & 18.3 & 31.9 & 16.3 \\
1991 & 12.6 & 12.9 & 11.1 & 23.1 & 35.9 & 14.8 & 14.2 \\
\hline
\end{tabular}


Table 6: Rates of profit remittance, average annual profits remitted and sterling rates of return for UK manufacturing investments in SSA, 1980-87 and 1988-92

\begin{tabular}{|c|c|c|c|c|c|c|c|c|}
\hline \multirow[b]{2}{*}{ Country } & \multicolumn{3}{|c|}{$\%$ profits remitted } & \multicolumn{3}{|c|}{ Ave annual profits remitted } & \multicolumn{2}{|c|}{ UK rate of return } \\
\hline & 1980-87 & 1988-92 & Difference & 1980-87 & 1988-92 & $\%$ & 1980-87 & 1988-92 \\
\hline \multicolumn{9}{|c|}{ Large improvements } \\
\hline Nigeria & 29.9 & 20.8 & -9.1 & 10.6 & 4.4 & -140.9 & 10.3 & 4.9 \\
\hline $\begin{array}{l}\text { Zimbabw } \\
\text { e }\end{array}$ & 23.5 & 31.9 & 8.4 & 6.4 & 10.1 & 57.8 & 4.5 & 6.3 \\
\hline \multicolumn{9}{|c|}{$\underline{\text { Small improvements }}$} \\
\hline Kenya & 38.0 & 29.8 & -8.2 & 4.4 & 5.6 & 27.2 & 2.8 & 6.4 \\
\hline Malawi & 30.8 & 32.8 & 2.0 & 0.6 & 1.5 & 150.0 & 2.5 & 5.0 \\
\hline \multicolumn{9}{|c|}{ Deterioration } \\
\hline Zambia & 22.4 & 7.7 & -14.7 & 2.2 & 1.0 & -120.0 & 5.0 & 3.4 \\
\hline Africa & 33.1 & 29.9 & -3.2 & 37.0 & 39.2 & -5.9 & 5.5 & 6.0 \\
\hline
\end{tabular}

Notes: Profits are post-tax 
Table 7: Change in nominal value (pounds sterling) of production among British manufacturing subsidiaries in anglophone SSA, 1989 and $1993(1989=100)$.

\begin{tabular}{|c|c|c|c|c|c|c|c|}
\hline \multirow[b]{2}{*}{ Country } & \multicolumn{3}{|c|}{ Decrease } & \multicolumn{4}{|c|}{ Increase } \\
\hline & $<\mathbf{5 0}$ & $51-75$ & 76-99 & $100-125$ & $126-150$ & $150>$ & $\mathbf{N}$ \\
\hline \multicolumn{8}{|c|}{ Large improvements } \\
\hline Ghana & 0.0 & 33.3 & 0.0 & 0.0 & 33.3 & 33.3 & 3 \\
\hline Nigeria & 15.0 & 5.0 & 10.0 & 20.0 & 30.0 & 15.0 & 20 \\
\hline Tanzania & 100.0 & 0.0 & 0.0 & 0.0 & 0.0 & 0.0 & 1 \\
\hline Zimbabwe & 25.0 & 33.3 & 8.3 & 16.7 & 0.0 & 16.7 & 12 \\
\hline Sub-total & 19.4 & 16.7 & 8.3 & 13.9 & 19.4 & 22.2 & 36 \\
\hline \multicolumn{8}{|c|}{ Small improvements } \\
\hline Malawi & 50.0 & 16.7 & 0.0 & 0.0 & 16.7 & 16.7 & 6 \\
\hline Kenya & 11.1 & 22.2 & 11.1 & 22.2 & 11.1 & 22.2 & 9 \\
\hline Uganda & 0.0 & 0.0 & 100.0 & 0.0 & 0.0 & 0.0 & 1 \\
\hline Sub-total & 25.0 & 18.8 & 12.5 & 12.5 & 12.5 & 18.8 & 16 \\
\hline \multicolumn{8}{|c|}{ Deterioration } \\
\hline Sierra & 0.0 & 100.0 & 0.0 & 0.0 & 0.0 & 0.0 & 1 \\
\hline Leone & & & & & & & \\
\hline Zambia & 100.0 & 0.0 & 0.0 & 0.0 & 0.0 & 0.0 & 3 \\
\hline Sub-total & 75.0 & 25.0 & 0.0 & 0.0 & 0.0 & 0.0 & 4 \\
\hline \multicolumn{8}{|l|}{$\underline{\text { Others }}$} \\
\hline Lesotho & 0.0 & 0.0 & 0.0 & 100.0 & 0.0 & 0.0 & 1 \\
\hline Swaziland & 0.0 & 50.0 & 50.0 & 0.0 & 0.0 & 0.0 & 4 \\
\hline Sub-total & 0.0 & 40.0 & 40.0 & 20.0 & 0.0 & 0.0 & 61 \\
\hline Overall & 23.0 & 19.6 & 11.5 & 13.1 & 14.7 & 18.0 & 100 \\
\hline
\end{tabular}


Table 8: Factors most likely to encourage investment - 1989 and 1994 survey responses (percentages)

\begin{tabular}{|cccccccccc|}
\hline Year & $\begin{array}{c}\text { FOREX } \\
\text { avail. }\end{array}$ & $\begin{array}{c}\text { FOREX } \\
\text { remitt- } \\
\text { ance }\end{array}$ & $\begin{array}{c}\text { FOREX } \\
\text { stability }\end{array}$ & $\begin{array}{c}\text { Econ. } \\
\text { growth/ } \\
\text { stability }\end{array}$ & $\begin{array}{c}\text { Politica } \\
\text { I } \\
\text { stability }\end{array}$ & $\begin{array}{c}\text { Less } \\
\text { corrup- } \\
\text { tion }\end{array}$ & $\begin{array}{c}\text { Skill } \\
\text { avail. }\end{array}$ & Others \\
\hline 1989 & 16.3 & 20.9 & 2.3 & 23.3 & 9.3 & 7.0 & 0.0 & 20.9 \\
1994 & 26.0 & 18.0 & 12.0 & 12.0 & 10.0 & 2.0 & 4.7 & 15.3 \\
\hline
\end{tabular}

